\title{
Ethical issues on the "synthetic" phosphoethanolamine clinical trial
}

\author{
Francisco José Roma Paumgartten ${ }^{1 *}$ \\ ${ }^{1} \mathrm{MD}$, PhD, National School of Public Health, Fundação Oswaldo Cruz, Rio de Janeiro, RJ, Brazi
}

Study conducted at the National School of Public Health, Fundação Oswaldo Cruz (Fiocruz), Rio de Janeiro, RJ, Brazil

Article received: $8 / 18 / 2016$ Accepted for publication: 10/19/2016

*Correspondence: Address: Av. Brasil, 4.036, salas 101-104 e 913 Rio de Janeiro, RJ - Brazil Postal code: 21040-361 paum@ensp.fiocruz.br

http://dx.doi.org/10.1590/1806-9282.63.05.388

\section{SUMMARY}

Notwithstanding its approval by the National Committee for Ethics in Research (Conep) on April 19, 2016, a trial of the so-called "synthetic" phosphoethanolamine (syn-phospho) pill in cancer patients raises ethical concerns. An analysis by a laboratory contracted by the Ministry of Science, Technology and Innovation (MCTI) revealed that syn-phospho contained a great amount of impurities and did not meet standards of pharmaceutical quality required for an investigational drug. Cytotoxicity against human tumor cell lines and in vivo rodent xenograft tumor assays consistently failed to demonstrate a potential anticancer activity of syn-phospho. Preclinical safety studies of syn-phospho were also insufficient to support a trial of this investigational drug in cancer patients. Moreover, the ethical approval decision apparently overlooked two previous findings that suggested a possible enhancement of mammary carcinoma cell proliferation by phosphoethanolamine, and an apparent increase in lung metastases (rat implanted tumor assay) by syn-phospho. The syn-phospho risk-benefit ratio is clearly unfavorable and, thus, this trial in cancer patients does not fulfill a key requirement to make a clinical research ethical. There are also concerns regarding whether the study design is robust enough (scientific validity), and the social value of the trial of syn-phospho in cancer patients is questionable.

Keywords: bioethics, clinical trial, investigational new drugs, neoplasms, preclinical drug evaluation, risk-benefit assessment.
According to a nationwide registry of research in human subjects (www.saude.gov.br/plataformabrasil), the National Committee for Ethics in Research (Conep) cleared a clinical trial protocol entitled: "Evaluation of safety and efficacy of synthetic phosphoethanolamine in patients with advanced solid tumors" on April 19, 2016. A further search on the National Agency of Sanitary Surveillance (Anvisa) online registry of clinical trials (http:// portal.anvisa.gov.br/consulta-de-ensaios-clinicos-autorizados) indicated that the agency did not authorize this new oncologic drug study in patients. As far as an investigational drug is concerned, for the sake of best protection of research subjects, clearance of clinical research by both Conep and Anvisa is required. It is of note that Anvisa is theoretically better equipped than Conep for a thorough analysis of preclinical data and clinical study protocols.

Furthermore, a bill that authorizes production, prescription and consumption of syn-phospho as an anticancer medication passed the Congress and the president signed it into law (Law 13,269/2016) on April 13, 2016. Since syn-phospho remains nearly untested for safety and efficacy, this law represents an unprecedented shortcut for a normally lengthy, costly and highly selective way to develop and approve a new drug for marketing. The syn-phospho law was challenged by a lawsuit (Direct Unconstitutionality Action) filed by the Brazilian Medical Association (AMB) and the full board of the Federal Supreme Court (STF) suspended its efficacy until a final decision by the court. The STF ministers who voted for a temporary suspension of syn-phospho law cited the lack of clinical studies in their declaration of vote.

Notwithstanding the approval by the Conep system, the syn-phospho trial in cancer patients does not fulfill at least three of seven key requirements to make a clinical research ethical. These requirements to protect the people participating in research (i.e., value, scientific validity, fair subject selection, favorable risk-benefit ratio, independent review, informed consent and respect to enrolled subjects) are found in universally accepted codes, 
declarations and other documents, and were clearly delineated by Emanuel et al. ${ }^{1}$

A first concern about the syn-phospho clinical study refers to whether its potential benefits for patients and the knowledge gained by society do in fact outweigh the risks for participants. One can always say that any clinical trial of a new drug or therapeutic intervention poses risks to subjects no matter how many nonclinical tests have preceded them. Owing to uncertainties regarding extrapolation between species and other methodological limitations of toxicity tests, preclinical safety evaluations can never rule out entirely the risks posed by a new medicine to patients. Nonetheless, regulators, bioethicists and most scientists agree that preclinical safety studies can disclose a number of potentially serious health hazards posed by a new and previously untested drug. ${ }^{2}$ Therefore, the conclusion that an investigational drug is reasonably safe to be tested in humans must always stand on the best evaluation of data from nonclinical in vitro and in vivo studies.

Guidelines for clinical development of new pharmaceutical products issued by different regulatory agencies and international organizations are clear about this ethical requirement. The guidance by the Council for International Organizations of Medical Sciences (CIOMS) and the World Health Organization (CIOMS-WHO), for instance, states explicitly (comments to guideline 8): “[...] clinical testing must be preceded by adequate laboratory or animal experimentation to demonstrate a reasonable probability of success without undue risk."3

The trial of syn-phospho in cancer patients does not comply with this ethical requirement because there are few preclinical studies on this compound and available data point towards an unfavorable risk-benefit ratio. Not only did laboratory and animal screening tests fail to demonstrate a potential anticancer activity, but also syn-phospho toxicity profile available at the time of ethical approval decision and trial onset were clearly insufficient to support test in humans. Moreover, Conep overlooked data from two experimental studies suggesting possible harm to cancer patients.

The first major problem with this clinical trial protocol is the poor characterization of the "new" drug under investigation. ${ }^{4}$ Phosphoethanolamine $\left(\mathrm{NH}_{2} \mathrm{CH}_{2} \mathrm{OPO}_{3} \mathrm{H}_{2}\right.$, syn phosphorylethanolamine, O-phosporylethanolamine; CAS Number 1071-23-4; Molecular weight 141.06) is an intermediate in the synthesis of phospholipids that serve as components of cell membranes. Within the cells, it is formed by ethanolamine kinase-mediated phosphorylation of ethanolamine. This primary amine can also be synthesized in the laboratory and a highly pure phospho- ethanolamine (O-phosphoethanolamine $\geq 99.0 \%$ pure) is offered by a commercial supplier (Sigma-Aldrich Product Catalog Number \# 27640). Phosphoethanolamine, irrespective of whether its origin is endogenous or exogenous, is a single molecule, thus receiving identical Chemical Abstract Service (CAS) Registry number.

Gilberto Chierice and coworkers, however, placed the adjective "synthetic" before phosphoethanolamine to label the chemical synthesized at their own laboratory (at the University of São Paulo, São Carlos campus). In six articles, Chierice and coworkers reported the effects of syn-phospho on cytotoxicity and xenograft tumor rodent assays. ${ }^{5-10}$ It is of note that in five of these six studies the authors did not declare the purity of the test compound, ${ }^{5-7,9,10}$ and in one study they informed that syn-phospho (analyzed by high-performance liquid chromatography) was $99 \%$ pure. ${ }^{8}$ A Nuclear Magnetic Resonance (NMR) analysis conducted by an independent laboratory (University of Campinas - Unicamp) contracted by the Ministry of Science Technology and Innovation (MCTI), however, found that phosphoethanolamine accounted for only $32.2 \%$ of the so-called "synthetic" phosphoethanolamine. ${ }^{4}$ The remaining constituents were impurities such as of Ca-, Mg-, Fe-, Mn-, Al-, Zn- and Ba-phosphates (34.9\%), monoethanolamine (18.2\%), pyrophosphates (3.6\%) and phosphobisethanolamine (3.9\%). ${ }^{4}$ The diversity and amount of impurities in syn-phospho indicate that its effects on nonclinical and clinical tests may result from constituents other than phosphoethanolamine, or even to an interaction between constituents.

In any clinical trial application, regulatory agencies generally require from investigators and sponsors sufficient information regarding pharmaceutical quality, or the proper identification, quality, purity and strength of the investigational drug. The drug's pharmaceutical quality must also be uniform and consistent across batches used in preclinical and clinical studies to ensure that the preclinical safety evaluation and subsequent clinical trials tested essentially the same investigational drug product. Based on the results from the MCTI-contracted chemical analysis, syn-phospho is far from meeting standards of pharmaceutical quality required for investigational drugs.

In December 2015, the MCTI contracted a limited set of preclinical studies of syn-phospho consisting of in vitro assays (cytotoxicity, and genotoxicity tests) and in vivo rodent (acute toxicity, mouse bone-marrow micronucleus test, rodent xenograft tumor test, and 7 and 28 day repeated oral dose test in rats). ${ }^{11}$ These preclinical studies were still in progress when the Conep approved the clinical trial protocol and thus it is unclear whether 
their results influenced the Committee's decision-making. At any rate, this limited set of toxicity tests is clearly insufficient to support a clinical trial of an investigational drug. A sub-chronic/chronic toxicity study (longer than 28 days) in both rodent and non-rodent species, for instance, is missing. The fact that phosphoethanolamine is a natural substance and that syn-phospho pills are already in use by many cancer patients is not a valid argument for waiving a thorough preclinical safety assessment of this investigational drug. Drug adverse effects other than short-term toxicity generally remain unrecognized unless experimental and/or epidemiology observational studies are conducted.

The guidelines by the International Council on Harmonisation of Technical Requirements for Registration of Pharmaceuticals for Human Use (e.g., ICH guidelines for non-clinical safety studies to conduct clinical trials) ${ }^{2}$ clearly state that: "Nonclinical safety studies [...] should be adequate to characterise potential adverse effects that might occur under the conditions of the clinical trial to be supported." According to the ICH recommendations and other guidelines, a nonclinical safety evaluation must include repeated-dose studies in two species (one non-rodent), the duration of which should be at least equivalent to that of the clinical trial to be supported (e.g., to support a 6-month clinical trial, durations of nonclinical repeated dose assays must be 6 -month or longer). Repeated dose studies in two species with adequate duration to support a clinical study of syn-phospho in cancer patients were not available, nor were these studies in progress or even contracted by the MCTI at the time of research protocol approval and trial onset. Furthermore, a study by Kano-Sueoka et al. ${ }^{12}$ found that phosphoethanolamine was a growth factor of rat mammary carcinoma cells in culture, while results from a study contracted by the MCTI suggested that syn-phospho may have enhanced the number of lung metastases in rats implanted with Walker 256 carcinosarcoma. ${ }^{13}$

It is noteworthy that experimental tests on a possible anticancer activity of syn-phospho or (pure) phosphoethanolamine yielded disappointing results. The studies by Chierice and coworkers ${ }^{5-10}$ and those further contracted by the MCTI ${ }^{12,13}$ showed consistently that syn-phospho has very low cytotoxicity. Syn-phospho was toxic to tumor and non-tumor cell lines only in the $\mathrm{mM}\left(10^{-3} \mathrm{M}\right)$ concentration range while most oncologic drugs used in clinical practice (e.g., sunitinib, cisplatin, doxorubicin, and more) are toxic to cancer cell lines at $\mu \mathrm{M}\left(10^{-6} \mathrm{M}\right)$ or even $\mathrm{nM}$ $\left(10^{-9} \mathrm{M}\right)$ concentrations. Moreover, the effects of syn-phospho on rodent xenograft tumor growth were modest and inconsistent across experiments. ${ }^{11,13}$ Chierice et al. ${ }^{6-8}$ used the intraperitoneal (ip) route (an unlikely route of administration for a human drug) to treat immunocompetent mice bearing transplanted tumors and thus indirect effects of ip administered syn-phospho (and its impurities) on tumor growth mediated by immune-stimulation cannot be ruled out.

In summary, not only preclinical safety studies are insufficient (and there exist concerns regarding a possible stimulation of cancer cell proliferation), but also experimental studies failed to find evidence that syn-phospho has an antitumor activity. In other words, there is no reasonable prospect that syn-phospho (or highly pure phosphoethanolamine) would bring concrete benefits to cancer patients and, in addition, the nonclinical toxicity profile is limited and unclear.

A second concern refers to the scientific validity of the clinical study. To be scientifically valid, a trial must be soundly designed and robust to demonstrate whether syn-phospho is an effective and safe oncologic drug. Unfortunately, contrasting to FDA clinical trial register system, Brazil's platform registry does not allow the public to learn about the study's design. It is unclear, for instance, whether this is a randomized trial. Random assignment and concealed allocation of trial participants are necessary to avoid systematic differences between baseline characteristics of groups that are being compared. Randomization is particularly complex in oncologic treatment trials. Although not providing details on the inclusion and exclusion criteria, the Brazilian platform registry informs that patients diagnosed with 11 different general ICD codes will be eligible. Taking into account that enrolled patients possibly are at different stages of the disease, that they underwent different prior therapies and are under different concomitant treatments, investigators will face a tremendous challenge in comparing drug effects on two groups of this highly heterogeneous population of patients. What are the clinical efficacy endpoints selected for this trial (overall survival, progression-free survival, time to progression, time to treatment failure, event-free survival, and so on) $?^{14}$ Moreover, how did investigators estimate the sample size needed to provide a statistically and clinically meaningful response to the central research question (anticancer efficacy and safety of syn-phospho)?

A third concern refers to the social value of this trial. As mentioned above, preclinical studies failed to demonstrate the antitumor activity of syn-phospho. In addition, no documented case report and no medical records corroborated the anecdotal reports saying that patients with cancer improved after taking syn-phospho pills. It is fair 
to conclude, therefore, that there is nothing but unfounded rumors to support the syn-phospho clinical trial. Since the underlying hypothesis that syn-phospho would be an effective oncologic drug is weak, not to say very unlikely, on what grounds does the social value of this clinical trial stand? One could argue that there is a pressing need to respond to a "clamor by society" regarding the alleged anticancer effects of syn-phospho, and that this "clamor" would be sufficient to justify a clinical trial. From a medical ethics standpoint, this argument is questionable because it is not fair to expose patients to a novel drug with its inherent health risks - including a possible adverse impact on the patient's adherence to a well-established oncologic treatment - if there are no reasonable prospects of therapeutic benefits. In other words, it does not seem to be ethically acceptable to conduct a clinical trial just to put an end to an unfounded rumor. There is no doubt that there is a pressing need to respond to society's questions on this matter. The straightforward answer, however, should be that available scientific evidence indicates clearly that syn-phospho has no potential antitumor activity and thus there is no convincing rationale for conducting a clinical trial in cancer patients. Needless to reaffirm, for the sake of the patients' best protection and health benefits, that clinical research must conform to generally accepted scientific and ethical principles, as well as be supported by scientific literature and results from previous nonclinical laboratory and animal studies.

\section{Resumo}

Questões éticas sobre o ensaio clínico da fosfoetanolamina "sintética"

Não obstante a sua aprovação pela Comissão Nacional de Ética em Pesquisa (Conep) em 19 de abril de 2016, um ensaio da pílula de fosfoetanolamina "sintética" (sin-fosfo) em pacientes com câncer levanta preocupações éticas. Uma análise feita por um laboratório contratado pelo Ministério da Ciência, Tecnologia e Inovação (MCTI) revelou que a sin-fosfo continha grande quantidade de impurezas e não satisfazia os padrões de qualidade farmacêutica exigidos para um medicamento experimental. Os ensaios de citotoxicidade com linhagens de células originárias de tumores humanos e testes in vivo em roedores com tumores xeno-enxertados falharam consistentemente em demonstrar uma potencial atividade anticân- cer da sin-fosfo. Os estudos pré-clínicos de segurança da sin-fosfo também foram insuficientes para apoiar a realização de um ensaio desse medicamento experimental em pacientes com câncer. Além disso, a aprovação ética aparentemente desconsiderou dois achados anteriores, sugerindo uma possível exacerbação da proliferação de células de carcinoma de mama pela fosfoetanolamina, e um aparente aumento de metástases pulmonares (ensaio de tumores implantados em ratos) pela sin-fosfo. A relação risco-benefício é claramente desfavorável para a sin-fosfo e, portanto, esse ensaio em pacientes com câncer não atende um requisito essencial para que uma pesquisa clínica seja ética. Há também preocupações quanto ao delineamento do estudo ser suficientemente robusto (validade interna), e o valor social do ensaio da sin-fosfo em pacientes com câncer é questionável.

Palavras-chave: bioética, ensaio clínico, novo medicamento experimental, neoplasias, avaliação pré-clínica de medicamentos, ponderação risco-benefício.

\section{References}

1. Emanuel EJ, Wendler D, Grady C. What makes clinical research ethical? JAMA. 2000; 283(20):2701-11

2. International Conference on Harmonisation of Technical Requirements for Registration of Pharmaceuticals for Human Use (ICH). ICH guideline M3 (R2) on non-clinical safety studies for the conduct of human clinical trials and marketing authorisation for pharmaceuticals EMA/CPMP/ICH/ 286/ 1995 .

3. Council for International Organizations of Medical Sciences (CIOMS), World Health Organization (WHO). International Ethical Guidelines for Biomedical Research Involving Human Subjects. Geneva; 2002.

4. Dias, LC, Dessoy MA, Barreiro EJ Caracterização do conteúdo das cápsulas de fosfoetanolamina (FOS) para o MCTI [cited 2016 Jul 12]. Available from: http://www.mcti.gov.br/fosfoetanolamina.

5. Arruda MSP, Correa MA, Venturini J, Félix MC, De Rosis AMB, Galhiane MS, et al. The effect of phosphoethanolamine intake on mortality and macrophage activity in mice with solid Ehrlich tumors. Braz Arch Biol Technol. 2011; 54(6):1203-10.

6. Ferreira AK, Meneguelo R, Marques FL, Radin A, Ribeiro Filho OM, Claro Neto $S$, et al. Synthetic phosphoethanolamine a precursor of membrane phospholipids reduce tumor growth in mice bearing melanoma B16-F10 and in vitro induce apoptosis and arrest in $\mathrm{G} 2 / \mathrm{M}$ phase. Biomed Pharmacother. 2012; 66(7):541-8.

7. Ferreira AK, Meneguelo R, Pereira A, Mendonça Filho O, Chierice GO, Maria DA. Anticancer effects of synthetic phosphoethanolamine on Ehrlich ascites tumor: an experimental study. Anticancer Res. 2012; 32(1):95-104.

8. Ferreira AK, Santana-Lemos BA, Rego EM, Filho OM, Chierice GO, Maria DA. Synthetic phosphoethanolamine has in vitro and in vivo anti-leukemia effects. Br J Cancer. 2013; 109(11):2819-28.

9. Ferreira AK, Meneguelo R, Pereira A, Ribeiro Filho OM, Chierice GO, Maria DA. Synthetic phosphoethanolamine induces cell cycle arrest and apoptosis in human breast cancer MCF-7 cells through the mitochondrial pathway. Biomed Pharmacother. 2013; 67(6):481-7.

10. Ferreira AK, Freitas VM, Levy D, Ruiz JL, Bydlowski SP, Rici RE, et al. Antiangiogenic and anti-metastatic activity of synthetic phosphoethanolamine. PLoS One. 2013; 8(3):e57937. 
11. Instituto Nacional do Câncer José Alencar Gomes da Silva - INCA. Relatório do seminário sobre estudos preliminaries da fosfoetanolamina sintética (FOS). 2016. Available from: http://www.mcti.gov.br/fosfoetanolamina.

12. Kano-Sueoka T, Cohen DM, Yamaizumi Z, Nishimura S, Mori M, Fujiki H Phosphoethanolamine as a growth factor of a mammary carcinoma cell line of rat. Proc Natl Acad Sci USA. 1979; 76(11):5741-4

13. Universidade Federal do Ceará - UFC. Faculdade de Medicina, Núcleo de Pesquisa e Desenvolvimento de Medicamentos - NPDM. Laudo técnico do estudo da fosfoetanolamina sintética: avaliação da possível atividade anticâncer da fosfoetanolamina sintética (FS) no carcinossarcoma 256 de Walker. Fortaleza: Laboratório de Oncologia Experimental; 2016 [cited 2016 Jul 12]. Available from: http://www.mcti.gov.br/fosfoetanolamina.

14. U.S. Department of Health and Human Services Food and Drug Administration Center for Drug Evaluation and Research (CDER), Center for Biologics Evaluation and Research (CBER). Guidance for industry: clinical trial endpoints for the approval of cancer drugs and biologics. May 2007. [cited 2016 Feb 22] Available from: https://www.fda.gov/downloads/drugs Guidance Compliance RegulatoyInformation/Guidance/UCM071590.pdf 